\title{
УДОСКОНАЛЕННЯ ПОДАТКОВОЇ ПОЛІТИКИ УКРАЇНИ В УМОВАХ ПОШИРЕННЯ ПАНДЕМIÏ COVID-19
}

\section{IMPROVEMENT OF UKRAINE'S TAX POLICY IN THE CONDITIONS OF THE COVID-19 PANDEMIC}

\author{
Назаркевич Ігор Богданович \\ доктор економічних наук, доцент, \\ Львівський національний університет імені Івана Франка \\ ORCID: https://orcid.org/0000-0001-5856-531X \\ Вовк Вікторія Вікторівна \\ студентка, \\ Львівський національний університет імені Івана Франка \\ ORCID: https://orcid.org/0000-0002-0386-9014

\section{Корпан Андріана Валеріївна} \\ студентка, \\ Львівський національний університет імені Івана Франка \\ ORCID: https://orcid.org/0000-0001-9112-5818 \\ Nazarkevych Ihor, Vovk Viktoriia, Korpan Andriana \\ Ivan Franko National University of Lviv
}

\begin{abstract}
В статті розглянуто необхідність удосконалення вітчизняної податкової політики в умовах поширення негативних соціально-економічних наслідків зумовлених пандемією COVID-19. Проаналізовано динаміку податкових надходжень у структурі державного бюджету в умовах корона кризи. Детерміновано перелік змін до нормативно-правових актів в податковій сфері спрямованих на покращення інвестиційного клімату у національній економіці. Запропоновано низку податкових заходів, спрямованих на підтримку підприємницького сектору в умовах пандемічних обмежень, зокрема обґрунтовано необхідність скорочення кількості податків, відтермінування податкових зобов'язань і строків подання податкових декларацій, вироблення грасріків платежів, що дадуть змогу роботодавцям сплачувати внески частинами, покращення податкових цифрових сервісів тощо.
\end{abstract}

Ключові слова: податкова політика, податкова система, підтримка бізнесу, пандемія, підприємництво.

В статье рассмотрена необходимость усовершенствования отечественной налоговой политики в условиях распространения негативных социально-экономических последствий, обусловленных пандемией COVID-19. Проанализирована динамика налоговых поступлений в структуре государственного бюджета в условиях корона кризиса. Детерминирован перечень изменений нормативно-правовых актов в налоговой сфере, направленных на улучшение инвестиционного климата в национальной экономике. Предложен ряд налоговых мер, направленных на поддержку предпринимательского сектора в условиях пандемических ограничений, в частности обоснована необходимость сокращения количества налогов, отсрочка налоговых обязательств и сроков представления налоговых деклараций, выработка графиков платежей, позволяющих работодателям платить взносы частями, улучшение налоговых цисровых сервисов и т.д.

Ключевые слова: налоговая политика, налоговая система, поддержка бизнеса, пандемия, предпринимательство.

The article considers the need to improve domestic tax policy in the context of the spread of negative socio-economic consequences of the COVID-19 pandemic. The list of changes to regulations in the tax sphere aimed at improving the investment climate in the national economy has been determined. A number of tax measures are proposed to support the business sector in the face of pandemic restrictions, including the need to reduce taxes, defer tax liabilities and deadlines for filing tax returns, schedule payment schedules that will allow employers to pay contributions in installments, etc. The current state of the tax system in Ukraine is analyzed in the article. The current situation in Ukraine is characterized by a general decline in business activity, declining revenues to the state budget and the liquidation of a number of enterprises that did not survive the crisis. The main problems of business struc- 
tures, the impact of the economic crisis on their functioning were also identified. Competent expansion of horizons of scientific research of tax policy in the conditions of the end of crisis, would contribute to the successful exit from it and strengthen economic security. The options for improving the tax policy in Ukraine to overcome the crisis situation and successfully overcome it have been identified. The importance of tax benefits, which include financial measures taken by the state to stimulate the economy, is highlighted. The article analyzes the state of tax revenues in the state budget in Ukraine in terms of years and the impact on it of the moratorium on entrepreneurship. The main changes in the legislation concerning tax benefits, tax assistance, subsidies, simplification of the taxation system in the business sphere are also highlighted. The importance of tax control for the successful implementation of tax and economic policy in the country is highlighted. The conditions in which Ukrainian business found itself after the moratorium were outlined, and its negative impact on the economic situation in Ukraine was assessed. It is important that the article highlighted the main directions of Ukraine's exit from the crisis situation in which it now finds itself. These include measures to stimulate, support enterprises and organize financial activities.

Keywords: tax policy, tax system, business support, pandemic, entrepreneurship.

Постановка проблеми. Пандемія коронавірусної хвороби COVID-19 та запровадження у зв'язку з цим обмеження спричинили істотні зміни у ринковій кон'юнктурі, що в свою чергу викликало зниження податкоспроможності господарюючих суб'єктів низки галузей. Все це призвело до зростання вразливості, насамперед малого і середнього бізнесу. Тому зміна системи податкових відносин в цих умовах $\epsilon$ одним з головних напрямів економічної політики держави.

COVID-19 має безпрецедентний вплив на спільноти в усьому світі. Достатньо подивитись на останні новини за 2020 рік, щоб переконатися у наявності широкого спектру медичних, економічних та соціальних впливів, які безпосередньо чи опосередковано викликані вірусом чи загострилися через пандемію. Багато мільйонів людей втратили роботу, а інші зіткнулися із закриттям їхніх підприємств, оскільки цілі виробничі сектори змушені були зупинити свою діяльність. Незважаючи на те, що найбільше безпосередні наслідки COVID-19 пов'язані зі здоров'ям, пандемія також торкається економічних питань. За оцінкою Міжнародної організації праці (МОП), при найнесприятливішому розвитку подій вплив пандемії на економічне зростання може призвести до зростання числа безробітних у всьому світі на 24,7 млн людей [3].

Аналіз останніх досліджень і публікацій. Питанням удосконалення вітчизняної податкової політики в умовах динамічних змін і кризових періодів присвячені праці низки українських учених, зокрема: О. Борзенко, А. Данилова, В. Дейнеки, Л. Демиденко, Н. Івасюк, А. Крисоватого, Г. Лещук, Н. Ментух, О. Шевчук та інших.

Проте отримані ефректи від пропозицій та змін у вітчизняному податковому законодавстві $€$ недостатніми, що потребує більш глибоких досліджень стосовно регулювання наслідків глобальних стохастичних кризових явищ, зокрема пандемії, на розвиток економіки України.

Метою статті $€$ дослідження умов карантинних обмежень і кризових явищ в економіці України та вироблення засобів державної податкової політики для підтримки соціальноекономічного розвитку і сталих темпів економічного зростання.

Виклад основного матеріалу. У всіх країнах з різними типами економіки податкова система визначає ступінь фрінансового благополуччя країни як джерело наповнення бюджету. В умовах фрінансової кризи важливе місце відводиться податковій системі як державному регулятору поліпшення фрінансової діяльності платників податків. При цьому, здійснюючи певні зміни в системі оподаткування, податкова політика повинна бути спрямована на оптимізацію інтересів держави (податкова наповнення бюджету) та податківців (оптимальна податкова навантаження). Немає умов для розвитку ринкових відносин, бізнесу та виходу економіки з кризи без максимально наближеною до оптимальної фріскальної політики у країні.

Теперішня вітчизняна податкова система не сприяє зростанню капітальних інвестицій в економіку Україну. Зокрема, комплектуючі імпортовані в Україну та призначені для подальшого реекспорту не мають оподатковуватися на загальних підставах. Також повне оподаткування імпорту інноваційного виробничого обладнання аналогів якому немає в Україні лише ускладнює інтеграцію вітчизняних підприємств у глобальні виробничі ланцюги.

Оподаткування імпорту має бути диверсисрікованим, наприклад найвищі ставки на товари кінцевого споживання і низькі ставки або нульові на пальне, сировину, інноваційне обладнання тощо.

Також не вирішеним є питання взаємодії підприємств платників податку на додану вартість (ПДВ) з господарюючими суб'єктами 
неплатниками ПДВ, оскільки унеможливлює отримання податкового кредиту. Відповідно для перших такі взаємовідносини є недостатньо вигідними.

Втім внесення змін до податкової систему будь-якої країни у бік послаблення чи збільшення податкового навантаження має певну ступінь ризику. Може виявитися проблемою та необґрунтованим захопленням стимулюючою фрункцією оподаткування системи в період фрінансової кризи. Зниження податкового навантаження чи прийняття державою додаткових витрат стимулюючого характеру веде до політичного ускладненням. В період економічного спаду доходи зменшуються, вживання підакцизних товарів різко скорочується, що призводить до зменшення надходжень до бюджету від цього податку, а в період економічного підйому, навпаки, надходження збільшується темпами, які перевищують темпи розвитку [4].

Податкові пільги та пакети заходів соціального захисту, спрямовані безпосередньо на тих, хто найменше здатний впоратися 3 кризою, мають найважливіше значення для пом'якшення руйнівних наслідків пандемії. Негайні заходи економічної допомоги, такі як гарантована оплачувана відпустка через хворобу, розширені допомоги по безробіттю, розподіл продовольства та загальний базовий заробіток, можуть допомогти уникнути гострих наслідків кризи [5].

Прогнозування податкових доходів в умовах поточної пандемії COVID-19 є складним завдання. Використання традиційних підходів до прогнозування, заснованих на простій динамічності податкової системи чи еластичності макроекономічних показників, швидше за все, призведе до заниженої оцінки скорочення доходів. Оскільки поточне потрясіння по-різному проявляється в різних секторах та залежно від розміру підприємств, більш достовірні результати можуть бути отримані, якщо розбити прогноз доходів за секторами та видами податків, ґрунтуючись на доступній інорормації щодо кожного сектору. У міру надходження нової інсрормації про пандемію та заходи у відповідь до прогнозів повинні вноситися відповідні зміни.

У більшості країн пандемія COVID-19 призвела до суттєвого скорочення податкових доходів. Це безпосередньо пов'язано зі зниженням економічної активності, а тим паче - із заходами податкової політики та адміністрування. Наслідки з якими зіткнуться домашні господарства та підприємства, призведуть до порушення економічної активності, характерне виключно для поточної кризи. Наприклад, необхідність соціального дистанціювання по-різному відбивається на податковій базі, податковому адмініструванні та дотриманні податкових норм платниками податків. Крім того, пандемія може надавати більш тривалий вплив на структуру економіки. Зовнішній сектор економіки деяких країн також може потрапити під удар, що призводить до знецінення чи девальвації валюти. Прояви такого впливу залежатимуть від структури економіки.

Незважаючи на значні складнощі, пов'язані з поточною ситуацією, прогнозування доходів держави надзвичайно важливо. При цьому відсутність точної інфрормації щодо розвитку пандемії та тривалості обмежувальних заходів, а також неточність оцінки ключових економічних показників призводять до деякої невизначеності прогнозів. Водночас для прогнозування доходів важливо повною мірою та послідовно використовувати припущення про хід пандемії та її вплив на економічне зростання. Також слід уникати внесення суб'єктивних фракторів і покладатися на очевидно неприйнятні методи. Адміністративним органам знадобиться і далі приймати важливі рішення щодо вибору заходів політики, керуючись максимально точною інформацією, зокрема прогнозами доходів.

Прозорість - стандартна умова використання суб'єктивних коригувань, у зв'язку з чим упорядники аналізу повинні представляти інфрормацію про характер і величину подібних коригувань за таких умов:

- враховуючи, що рівень доходу може бути нижчим, ніж при використанні простих підходів на основі динамічності.

- слід приділяти більше уваги короткостроковим прогнозам, а для довгострокових прогнозів (які виходять за рамки 2-річного періоду) на даний момент можна використовувати стандартні методи;

- кожен захід політики потребує окремого розгляду;

- варто коригувати прогнози в міру надходження нової інфрормації про пандемію та вживаних заходів у відповідь тощо [6].

Закон України «Про внесення змін до Податкового кодексу України та інших законів України щодо підтримки платників податків на період здійснення заходів спрямованих на запобігання виникненню і поширенню коронавірусної хвороби (COVID-19)», який був затверджений 18 березня 2020 року і став превентивним інструментом щодо мінімізації еко- 
номічних втрат в системі національного господарства. Також цим законом визначено зміни до Податкового кодексу України «Про збір та облік єдиного внеску на загальнообов'язкове державне соціальне страхування».

Відповідно до змін у Законі України «Про збір та облік єдиного внеску на загальнообов'язкове державне соціальне страхування», запроваджені такі дії:

- На деякий час позбавляється від обрахування та оплати єдиного внеску, що піддається нарахуванню і сплаті фрізичними особами, тобто підприємцями і тих, хто здійснює вільне профресійне діяння. До таких видів діяльності можна віднести: юридичну, художню, медичну, освітню тощо.

- На певний період скасовуються податкові штрафри щодо тих, хто сплачує Єдиний соціальний внесок (ЄСВ), зокрема за недотримання правил щодо невчасної або неповної його сплати.

Доволі правильним рішенням держави щодо підприємств стала ініціатива розвантажити бізнес податковими перевірками. На сьогоднішній день резерви підприємств повинні бути цілеспрямованими стосовно вирішення питань буття і відновлювання, а не на бюрократичні процедури.

Впровадження, які здійснила держава, на даний момент можуть відносно ослабити вплив економічної кризи. Однак, 3 погіршенням ситуації тапосиленням карантинних норм, Верховній Раді України потрібно буде дотримуватись більш серйозних методів боротьби з пандемією і та слідувати антикризовій процедурі розвинених країн заходу. Також і для тривалості термінів податкових і кредитних канікул, застосування опрацювання особливого плану та порядку сплати податків або запровадження спеціальних механізмів із загальнодоступного кредитування підприємства і виплати заробітної плати.

Беручи до уваги сьогоднішню дійсність, застосування схожих методів дасть змогу послабити наслідки пандемії для підприємств. Проте в той час буде для влади тяжким випробуванням на професійність. Але другої варіації виплутувати бізнес з кризових тенет не передбачається [7].

Зміни до нормативно-правових актів в податковій сорері, насамперед, спричинені гострою потребою в захисті та належній підтримці малого та середнього бізнесу в період посилених карантинних обмежень, зумовлених пандемією. Проте, в свою чергу, такі зміни є досить позитивними і сприяють гар- монізації законодавчих актів відповідно до міжнародних. 3 огляду на це, одним із ключових фракторів розвитку світової економіки є лібералізація податкової системи. Створення конкурентоздатної та соціально-орієнтованої економіки, яка сприятиме інтеграції в Європейську спільноту, надання гарантій в стабільному економічному зростанні, здійснення есрективної політики в бюджетній сорері не можна уявити без успішної реалізації збалансованої податкової політики для стимулювання та підтримки платників податків.

Варто наголосити на тому, що податкова політика, яка спрямована на наповнення бюджету різними способами, вирішуючи потреби адміністрації в той чи інший період, тим самим не формує, а руйнує національний капітал [8, с. 284].

Якість та результативність податкового контролю $€$ однією з основних умов успішного фрінансового управління. Контроль в ссрері оподаткування $€$ одним 3 видів державного фрінансового контролю, засобом цілеспрямованого впливу держави на суб'єктів господарської діяльності. Метою виступає забезпечення реалізації законодавчого обов'язку щодо сплати податків та своєчасного регулювання відхилень в податковому процесі.

Податкові перевірки стосуються питань, які безперервно хвилюють український бізнес. Згідно зі статистичними даними, незважаючи на всі впровадженні заходи для полегшення ведення бізнесу в період кризи, пов'язаної $з$ COVID-19, на початку 2020 року було отримано на 14\% відсотків більше скарг від підприємств, ніж в відповідному періоді попереднього року. Крім цього, якщо спершу кількість скарг зменшувалася і становила 3\%, то в 4-му кварталі їх кількість зросла на 26\%.

318 березня по 8 серпня 2020 року в Україні проводилися тільки деякі види податкових перевірок, на яких не було встановлено обмеження. Сюди слід віднести: камерні перевірки та позапланові документальні перевірки, що відбувалися перед відшкодуванням ПДВ, або у зв'язку з декларуванням великого його від'ємного значення. Від серпня 2020 року почали проводитися фрактичні перевірки щодо обігу підакцизних товарів (тютюн, пальне, алкогольні вироби), а також перевірки на основі звернень платників податків, так звані ліквідаційні перевірки.

3 лютого 2021 року було розширено дозволи на проведення перевірок. Зокрема відновилися: тимчасово призупиненні перевірки, які було розпочато на час запровадження морато- 
рію; документальні перевірки підприємницьких суб'єктів реального сектору економіки; перевірки дотримання строків приходу товарів за імпортними операціями та валютної виручки за експортними операціями. Також розпочалися позапланові перевірки, які виникли внаслідок розгляду скарг щодо дій чи бездіяльності органів контролю та щодо неправомірних нарахувань фрінансових зобов'язань платників податків. Причинами відновлення контролюючих дій з державної сторони стали руйнівні наслідки мораторію як для бюджету, так і для бізнес-структур, які працюють відкрито [9].

Крім цього, за час карантину відбулася низка нововведень в законодавство України. Зокрема, це стосується тимчасового звільнення від ПДВ операцій з ввезення на митну територію лікарських засобів, медичних виробів, медичного обладнання. Також припинилося застосування санкційних заходів щодо порушення податкового законодавства в період з 01.03.2020 по 31.05.2020. 3 18.03.2020 по 31.05.2021 було встановлено мораторій на проведення документальних та фрактичних перевірок. Ще одним нововведенням стало звільнення від нарахувань і подальшої сплати податку за землю, за нерухоме майно з нежитлових об'єктів, які $€$ у власності фрізичних чи юридичних осіб (з 01.03.2020 по 30.04.2020) та звільнення від сплати ЄСВ ФОПів, які проводять незалежну професійну діяльність, членів фермерського господарства (з 01.03.2020 по 31.03.2020).

За останній період у ВР України було подано ще кілька законопроектів, що стосуються змін до Податкового кодексу України щодо запровадження заходів з допомоги бізнес-структурам та запобігання поширення COVID-19. Але ставлення щодо їх досконалості в підприємців досить неоднозначне.

Тож, стає зрозумілим, що потрібна обдумана та виважена політика щодо урівноваження наявної ситуації, яка б стала гарантією врахування приватних та державних інтересів в умовах існуючої фрінансової кризи.

Сучасними напрямами податкової політики $€$ створення сприятливих податкових умов для ведення бізнесу завдяки використанню таких інструментів як зниження податкових ставок, відтермінування сплати податків, звільнення від оподаткування певних категорій платників податків, припинення на визначений період санкцій за порушення окремих норм податкового законодавства [10].

Затвердження та реалізація законопроектів щодо допомоги бізнесу, запобігання поши- ренню хвороби, обліку ЄСВ, підтримки збалансованості надходжень в бюджет, надання пільг тощо сприятиме полегшенню податкового навантаження на бізнес та забезпечуватиме виконання бюджетного плану за умов відповідних коригувань.

До прикладу, в 2020 році податкові надходження у структурі державного бюджету скоротилися на $6,17 \%$ в порівнянні 3 попереднім роком, а обсяг виконання державного бюджету зменшився на 30\%. При цьому, ставки податку на доходи фрізичних осіб (ПДФО), військового збору, податку на прибуток залишаються незмінними.

Зміни до податкового законодавства України пов'язані з потребою надання допомоги суб'єктам господарської діяльності в період пандемії. Вони $\epsilon$ есрективним інструментом, однак, їхня дієвість прямо залежить від обґрунтованої податкової політики. Тому, варто окреслити такі головні аспекти забезпечення ефективності роботи податкової системи в Україні:

- гнучкість та пристосованість до потреб національного бізнесу;

- формування умов для сталості основних макроекономічних показників економічного та соціального розвитку держави [11].

Аналізуючи динаміку податкових надходжень на рис. 1, можна побачити, що обсяг коштів, які надходили до бюджету України зростав в період 2014-2018 рр. Тоді як 3 2019 року, тобто з початку поширення кризи, пов'язаної з COVID-19, обсяг податкових надходжень скоротився на 14,6\% в порівняні 3 попереднім роком, а у 2020 році ще близько на $2 \%$. Все це $є$ наслідком зниження підприємницької активності, ліквідацією низки підприємств малого та середнього бізнесу, які не зуміли зберегти рентабельність та пристосуватися до існуючих умов.

Наявні обставини змушують модернізувати існуючі та шукати ефективніші напрямки подолання економічної кризи, які б допомагали відновленню та розвитку бізнессередовища.

В цьому контексті важливим в умовах пандемії $€$ цифрровізація податкових відносин. Загалом процеси оцифрування податків тривають уже кілька років. Результатом $€$ Електронний кабінет платника, єдиний податковий рахунок, електронні сервіси подання податкової звітності.

Однак вважаємо, що доцільним є формування і запровадження цифрової програми податкової персоніфрікації. Дана програма 


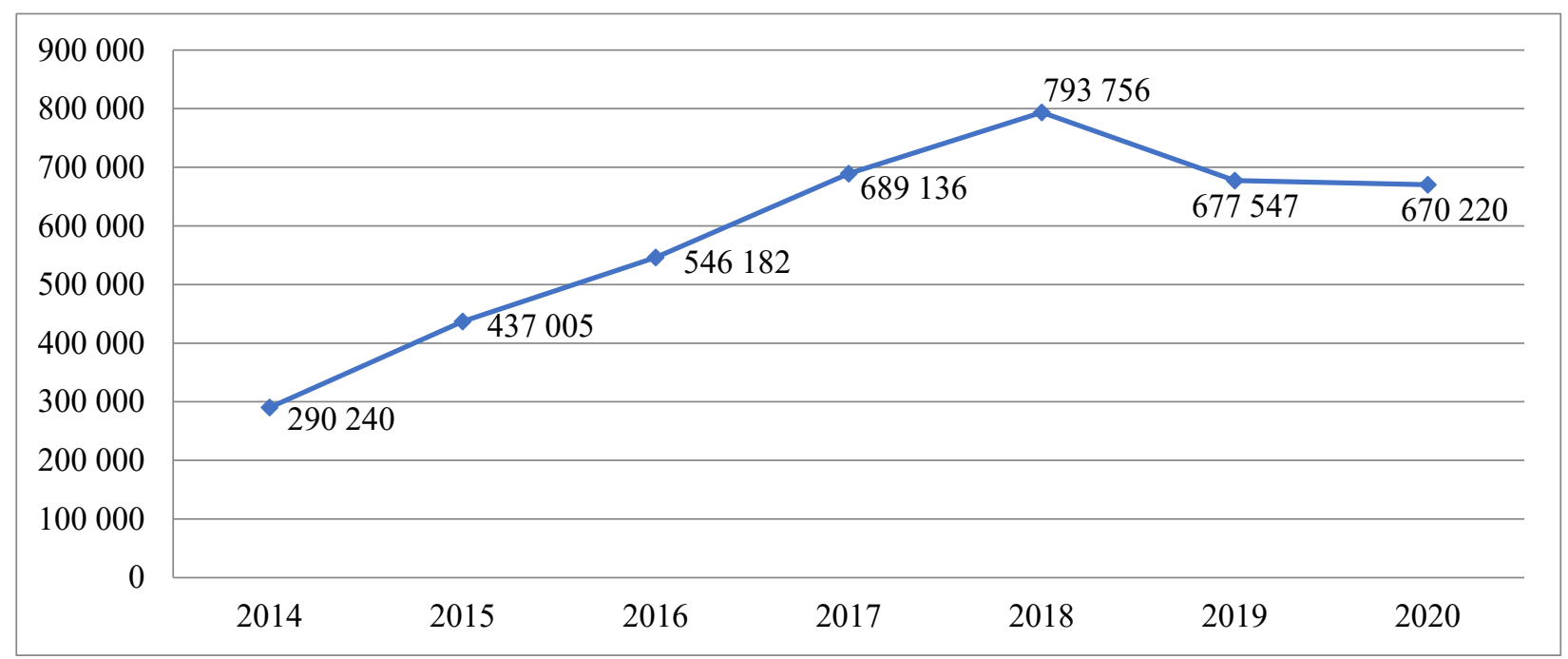

Рис. 1. Податкові надходження зведеного бюджету України, 2014-2020 рр., млн грн.

Джерело: складено авторами на основі [12]

дала б змогу відображати облік податкових платежів за окремим суб'єктом, зокрема фрізичною особою. Тобто, формування відповідного програмного сервісу дасть змогу будь якому платнику податків відстежувати аналітику сплачених ним податків і зборів, у тому числі усіх непрямих податків, якщо розрахункові операції здійснені з його рахунку. Це дало б змогу зменшити розрахунки готівкою, підвищити податкову дисципліну, збільшити громадянську активність і соціальну відповідальність платників.

Загалом, на нашу думку, напрямами удосконалення податкової політики в Україні в умовах пандемії мають бути:

- спрощення адміністрування ПДВ, у тому числі системи взаємозаліків;

- перехід від єдиної до прогресивної системи оподаткування за ПДФО;

- формування диверсифрікованої податкової підтримки залежно від виду економічної діяльності, а також від базової потреби господарюючого суб'єкта - підтримки ліквідності чи реінвестування у розширення бізнесу;

- запровадження податкових пільг при створенні додаткових робочих місць;

- підвищення ставок екологічного податку та рентних платежів;
- імплементація тимчасових стимулюючих заходів, спрямованих на ті сорери, де фріскальні мультиплікатори будуть найвищими;

- розширення дискреційних заходів фріскальної політики, зокрема посилення програм «трансорертного типу» (перерозподільчих).

Висновки. Отже, для успішного та ефрективного ведення підприємницької діяльності, розвитку економічної системи та сталості макроекономічних показників основною умовою виступає неупереджена, відкрита та зрозуміла податкова система 3 відповідною гнучкою та адаптивною політикою оподаткування. Зміни та нововведення, які відбулися в Україні прямо пов'язані 3 потребою захисту суб'єктів господарської діяльності в період кризи. Адже в період економічної кризи відбувся значний спад підприємницької активності і відповідно скорочення податкових надходжень до державного бюджету.

Важливим на сьогоднішній час залишається фрормування узгодженого, перспективного та дієвого плану дій щодо подолання наявної кризи, реалізація заходів з підтримки малого і середнього бізнесу, створення якісних комунікативних зв'язків 3 державними й приватними інститутами, використання ефрективних податкових механізмів, ставок та інструментів.

\section{СПИСОК ВИКОРИСТАНИХ ДЖЕРЕЛ:}

1. Податковий кодекс України № 2755-VI від 2 грудня 2010 p. URL: www.rada.gov.ua

2. Про внесення змін до Податкового кодексу України та інших законів України щодо підтримки платників податків на період здійснення заходів, спрямованих на запобігання виникненню і поширенню коронавірусної хвороби (COVID-19) : Закон України від № 533-IX від 17 березня 2020 p. URL: https://zakon.rada.gov.ua/laws/ show $/ 533-20$ 
3. Краткие аналитические обзоры COVID-19. Последние исследования, сведения и анализ в области влияния COVID-19 на миграцию и мигрантов в быстро меняющихся условиях. Исследовательская организация MOM. 155 c. URL: https://www.iom.int/sites/g/files/tmzbdl486/files/our_work/ICP/COVID-19_analytical_snapshotscompiled_russian_translation.pdf

4. Данилов А. Д. Податкова система України в умовах економічного спаду. Економічна наука. Економіка $i$ держава. 2010. № 3. C. 32-36. URL: http://www.economy.in.ua/pdf/3_2010/11.pdf

5. Protecting human rights amid COVID-19 crisis / United Nations. United Nations. URL: https://www.un.org/en/ un-coronavirus-communications-team/protecting-human-rights-amid-COVID-19-crisis

6. Проблемы прогнозирования налоговых доходов. МВФ / Бюджетные вопросы. С. 1-10.

7. Податки в епоху COVID-19. Юридична газета - онлайн версія. URL: https://yur-gazeta.com/publications/ practice/podatkova-praktika/podatki-v-epohu-COVID19.html

8. Шечук О. Р., Ментух Н. Ф. Податкові пільги як елемент підтримки суб'єктів господарювання в період боротьби з COVID-19: порівняльно-правовий аспект. Юридичний науковий електронний журнал. 2020. № 2. C. 283-286. URL: http://lsej.org.ua/2_2020/76.pdf

9. Національна Асоціація Адвокатів України - Фінансовий контроль за діяльністю бізнесу: реалії карантинного сьогодення. Національна Асоціація Адвокатів України. URL: https://unba.org.ua/publications/6510finansovij-kontrol-za-diyal-nistyu-biznesu-realii-karantinnogo-s-ogodennya.html

10. Національна Асоціація Адвокатів України - Оподаткування підприємництва в умовах фрінансової кризи: гармонізація публічного і приватного інтересу. Національна Асоціація Адвокатів України. URL: https://unba.org.ua/publications/6339-opodatkuvannya-pidpriemnictva-v-umovah-finansovoi-krizi-garmonizaciyapublichnogo-i-privatnogo-interesu.html

11. Лещук Г. В., Івасюк Н. Б. Податкова система України в умовах пандемії COVID-19: сучасні реалії та прогнози. Міжнар. екон. відносини та світ. госп-во. 2020. № 33(1). С. 87-92. URL: http://www.visnyk-econom.uzhnu.uz.ua/ archive/33_1_2020ua/18.pdf

12. Доходи бюджету України. Ціна держави - проект CASE Україна. URL: http://old.cost.ua/budget/revenue/

13. Заходи стимулювання бізнесу в умовах пандемії. НДІ фіскальної політики - Наука оптимальних податкових рішень. URL: https://www.ndifp.com/1479/

\section{REFERENCES:}

1. Podatkovyi kodeks Ukrainy № 2755-VI [Tax Code of Ukraine № 2755-VI]. Retrieved December 2, 2010. Retrieved from: www.rada.gov.ua

2. Pro vnesennia zmin do Podatkovoho kodeksu Ukrainy ta inshykh zakoniv Ukrainy shchodo pidtrymky platnykiv podatkiv na period zdiisnennia zakhodiv, spriamovanykh na zapobihannia vynyknenniu i poshyrenniu koronavirusnoi khvoroby (COVID-19) [On Amendments to the Tax Code of Ukraine and Other Laws of Ukraine on Support of Taxpayers for the Period of Measures Aimed at Preventing the Occurrence and Spread of Coronavirus Disease (COVID-19)]. Zakon Ukrainy [Law of Ukraine]. Retrieved March 17, 2020. Retrieved from: https://zakon.rada.gov.ua/ laws/show/533-20

3. IOM Research Organization. Poslednye yssledovanyia, svedenyia y analyz v oblasty vlyianyia COVID-19 na myhratsyiu y myhrantov $v$ bustro meniaiushchykhsia uslovyiakh [Recent research, information and analysis on the impact of COVID-19 on migration and migrants in a rapidly changing environment]. Brief analytical reviews of COVID-19, 155. Retrieved from: https://www.iom.int/sites/g/files/tmzbdl486/files/our_work/ICP/COVID-19_analytical_snapshots-compiled_russian_translation.pdf

4. Danylov A. D. (n.d.) Podatkova systema Ukrainy v umovakh ekonomichnoho spadu [Ukraine's tax system in conditions of economic downturn]. Economics - Economy and state, 3, 32-36. Retrieved from: http://www.economy.in.ua/ pdf/3_2010/11.pdf

5. United Nations. Protecting human rights amid COVID-19 crisis. Retrieved from: https://www.un.org/en/ un-coronavirus-communications-team/protecting-human-rights-amid-COVID-19-crisis

6. IMF. Problemy prohnozyrovanyia nalohovykh dokhodov [Problems of forecasting tax revenues]. Spetsyalnaia seryia publykatsyi po meram nalohovo-biudzhetnoi polytyky v otvet na COVID-19, 1-10. (in Russian)

7. Podatky v epokhu COVID-19 [Taxes in the COVID-19 era]. Legal newspaper-online version. Retrieved from: https://yur-gazeta.com/publications/practice/podatkova-praktika/podatki-v-epohu-COVID19.html

8. Shechuk O. R., Mentukh N. F. (2020) Podatkovi pilhy yak element pidtrymky sub'iektiv hospodariuvannia v period borotby z COVID-19: porivnialno-pravovyi aspect [Tax benefits as an element of support for businesses in the fight against COVID-19: a comparative legal aspect]. Legal scientific electronic journal, 2, 283-286. Retrieved from: http://lsej.org.ua/2_2020/76.pdf 
9. National Bar Association of Ukraine. Finansovyi kontrol za diialnistiu biznesu: realii karantynnoho sohodennia [Financial control over business activities: the realities of the quarantine present]. Retrieved from: https://unba.org.ua/ publications/6510-finansovij-kontrol-za-diyal-nistyu-biznesu-realii-karantinnogo-s-ogodennya.html

10. National Bar Association of Ukraine. Taxation of entrepreneurship in the financial crisis: harmonization of public and private interests [Opodatkuvannia pidpryiemnytstva $v$ umovakh finansovoi kryzy: harmonizatsiia publichnoho i pryvatnoho interesu]. Retrieved from: https://unba.org.ua/publications/6339-opodatkuvannya-pidpriemnictva-v-umovah-finansovoi-krizi-garmonizaciya-publichnogo-i-privatnogo-interesu.html

11. Leshchuk H. V., Ivasiuk N. B. (2020) Podatkova systema ukrainy v umovakh pandemii COVID-19: suchasni realii ta prohnozy [Tax system of Ukraine in the pandemic COVID-19: current realities and forecasts], 33(1), 87-92. Retrieved from: http://www.visnyk-econom.uzhnu.uz.ua/archive/33_1_2020ua/18.pdf

12. Dokhody biudzhetu Ukrainy [Budget revenues of Ukraine]. The price of the state is the CASE Ukraine project. Retrieved from: http://old.cost.ua/budget/revenue/

13. Zakhody stymuliuvannia biznesu $\mathrm{v}$ umovakh pandemii [Measures to stimulate business in a pandemic]. Research Institute of Fiscal Policy - The Science of Optimal Tax Decisions. Retrieved from: https://www.ndifp.com/1479/ 